\title{
Review
}

\section{Political ontology and international political thought: Voiding a pluralist world}

\author{
Vassilios Paipais \\ Palgrave Macmillan, London, 2017, xiv+241pp., \\ ISBN: 978-1-137-57068-0
}

Contemporary Political Theory (2019) 18, S232-S235. https://doi.org/10.1057/s41296018-0228-1; published online 14 May 2018

It has been argued that the birth of modernity resembles an explosion or, it would better to say, an implosion. The collapse of the ethical-political architecture of the res publica Christiana produced a fragmentation that the territorialisation of the faiths and churches was unable to reassemble into one whole (and, when so, only for a limited period of time). Moreover, this pluralism-in-fragments - grown in the shadow of the 'death of God' - was shaken even more by the subsequent 'wave of globalisation', which replaced the old principle of territorialisation (cuius regio, eius religio) with that of total mobilisation (cuius oeconomia, eius regio). Today, we live in a world that is literally made of slivers of worlds (values, symbols, objects) mixed without guidance (apart from the randomness driven by private interest). Accordingly, the question of pluralism is not merely theoretical, but also practical and political, as shown by the heated debate on 'Euro-Islam' and the so-called 'headscarf affair', the complex problem of migrants and asylum seekers, and the resurgence of nationalisms and identity politics which we have witnessed in recent years. A critical reflection on pluralism, both from a conceptual and a practical point of view, is, in short, more urgent than ever. But how is it possible to reconceptualise this 'unstable pluralism' in terms of a new unity-in-plurality that is no longer based on classical and exclusionary models the so-called 'particular universals' (the nation state, the 'free' market, citizenship)?

It is precisely this urgent question that animates this unusually powerful and deeply theoretical work - a book that is theoretically oriented towards an idea of praxis freed from the residues of any facile liberal universalism. In effect, in its pars destruens, Paipais' work offers a critical re-reading of the various theoretical paradigms that have confronted the problem of pluralism. As is well known, theoretical approaches to pluralism are characterised by a 'bipolar dialectic': on one hand, there are the anti-foundationalist and genealogical approaches that, inspired by Nietzsche's reflections, and later by Foucault's and Derrida's work, have emphasised the radical condition of contingency brought about by modernity - i.e. the necessity of relativism as the most adequate theoretical position in an age

(C) 2018 Macmillan Publishers Ltd., part of Springer Nature. 1470-8914 Contemporary Political Theory Vol. 18, S4, S232-S235 www.palgrave.com/journals 
when the 'will to truth has become conscious of itself as a problem in us' (Nietzsche, 2007, p. 119). On the other side of the spectrum stand the neo- and post-Kantian approaches that refused to abandon the subject (and its historical necessity) to chance but, on the contrary, have anchored it - epistemologically, ethically, and politically - into some 'universal categories' (space and time, human rights, humanity as the subject/object of law). The basic thesis of Paipais' book is that the new lines of thought that flowed from these two theoretical sources (e.g. Connolly's ethos of pluralisation and Rawls' liberalism), despite the diversity of forms and solutions they offer to the issue of pluralism, suffer from a common problem: a tendency towards depoliticisation.

With this technical term, Paipais describes those latent tendencies detectable within liberal, post-liberal, dialogic and agonistic approaches to pluralism 'to rely on foundationalist or anti-foundationalist understandings of ontology all the while sharing an approach to Being as an infinite yet closed totality' (p. xii). 'Depoliticisation', therefore, describes certain mechanisms of exclusion that operate (sometimes unconsciously) even within those theoretical positions that appear to openly embrace social diversity (e.g. Rorty's pragmatism). According to Paipais, what at first glance seems to be an exclusively theoretical problem - or better, a metatheoretical one, i.e. the ontological presuppositions of a conceptual apparatus - has a strong practical relevance. To capture the world as totalisation, in fact, prevents us from thinking the complexity of pluralism and its infinite dialectic of identity and difference, unity and multiplicity, inclusion and exclusion. In other words, the ontological totalisation that affects these systems of thought is a sort of 'repressed memory' of the implicit exclusivism that characterises them. As he put it, 'if political liberalism and some forms of critical dialogism are underpinned by an ontology that tends to prioritise the universal over the particular, post-Nietzschean political theory and radical democracy seem to be tempted by an ontology that programmatically celebrates diversity at the expense of unity, perpetuating the deadlocks of Western metaphysics' (p. 222). Thus, for example, Rawls' notion of 'reasonableness', although thought to open up political spaces to non-liberal worldviews, 'seems like an invitation to participate in an already predetermined non-negotiable framework of coexistence' (p. 140), i.e. Western public reason. In the same vein, but from a specular and inverted perspective, post-structural and agonistic approaches to pluralism (e.g. Connolly and Mouffe), by emphasising the plan of immanence as the ontological background of contemporary pluralism, end up transforming 'difference, contingency and multiplicity' into a 'form of reversed universalism' (p. 126).

At this conceptual juncture, then, one might wonder how it is possible to overcome the traps of exclusionist universalism ('every rational man is welcome in the liberal world') and of relativistic nihilism ('anyone and anything goes'). But is it actually possible to think of a political ontology that is both open (to the concrete diversity of pluralism) and closed (as a speculation on the essence/totality of Being)? According to Paipais, who follows here some Heideggerian suggestions and interpretations, the

(C) 2018 Macmillan Publishers Ltd., part of Springer Nature. 1470-8914 Contemporary Political Theory Vol. 18, S4, S232-S235 S233 
impasse can be overcome by using a twofold strategy: firstly, by rejecting the interpretation of ontology understood as a 'grounding ground'; i.e. as a totalising presence and cognitive foundation of a discourse (be it scientific, moral or political); and, secondly, by rethinking ontology as 'the formal non-ground... that operates as the condition of possibility/impossibility for the constitution of worldly objects' and political subjectivities (p. 15). In short, Paipais revisits and adopts the ontological difference introduced by Heidegger, but transposes it into the 'territory of the political', i.e. into the difference between politics (understood as the institutionalisation of power relations) and the political (understood as the violent and original energy that always permeates, and can overwhelm, the political form).

According to Paipais, within this never-quiet difference, in this always-alreadyopen abyss which is ontology, it is possible to glimpse a different form of political subjectivity, finally freed from the metaphysical residues and the debts contracted with Western-centric universalism. The new political subject, unbound from an always-already-predetermined plane of being, can now open herself up to history and experience social diversity authentically. Through her newfound authentic finitude, she can even rediscover classical theological virtues (e.g. hope), a new dimension of time (non-linear or teleological but kairotic) and social space (not merely political but also ethical, i.e. charity). Nonetheless, in these final pages, which are profoundly intriguing, Paipais' work seems to break up under the pressure of the theme.

In effect, the pars construens of the work (chapters 5-7), although sophisticated, lacks genealogical sensibility. In order to forge a new approach to pluralism and a novel ethical-political subject, Paipais brings together, a little too audaciously, Benjamin's messianic Marxism with Heideggerian ontology, and St. Paul's theology of history with Žižek's political reading of Lacan's psychoanalysis. At the end of this tour de force, the new political subject thus constructed looks more like a post-modern Frankenstein's monster than a historical individual capable of rediscovering the theological virtues of a liberated Christianity. As a matter of fact, subjectivity is also, and above all, the result of social and political practices. Outside their genealogical bed (outside their historical conditions of possibility, as Nietzsche would put it), both concepts and individuals cannot but be disoriented. In Kantorowicz's words, 'Practice, as usual, precede[s] theory; but existing practice [makes] the minds all the more receptive for a new theory' (1997, p. 273). Although theory is capable of instilling new life into concepts, a historical practice, merely built by means of a theory, remains somehow closed and meaningless to the practical subject. In short, the very same notions and principles which build up a world - like that of medieval Christianity, for example - are literally empty for those who do not share and live the metaphysical aspirations of that world. How it is then possible to fuse together, without confusing, concepts and precepts that have grown within different political worlds and social practices (Christianitas, psychoanalysis, modernity, etc.) and that, in the end, cannot but collide? In this sense, Paipais' critique ironically ends up reproducing the very postmodern fragmentation it seeks to overcome. 
To explain this crucial point, I would like to conclude by analysing the image of the crucifixion and the notion of glory that Paipais recalls - and wants to revitalise - in the last chapter of his fascinating book. One of the earliest representations (dated approximately between the first and third centuries C.E.) of the crucifixion was found at the end of the nineteenth century in the so-called domus Gelotiana, on the Palatine Hill in Rome. The graffito depicts a human-like figure affixed to a cross and possessing the head of a donkey. To the left of the image is a young man, apparently intended to represent a Roman soldier (named Alexamenos), in a gesture suggesting worship. Just beneath the cross is an ironic caption written in

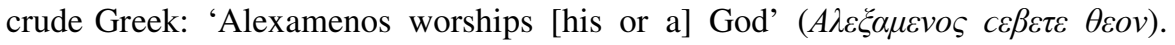
Crucifixion here is not understood as martyrdom and glory, but rather as weakness and blind faith in the senselessness of suffering. Without the sense-giving support of a new (and dominant) metaphysical system, sacrifice for pre-Christian pagans is merely conceived as humiliation and pain, finitude is nothing but defeat. In short, to make finitude 'productive' again - as Paipais seems to suggest in the conclusion it is necessary to imagine a new ethical vision of the world and of sacrifice. In fact, outside their metaphysical and historical background, the fundamental concepts of a religious tradition are nothing but empty shells.

For the originality of its interpretation, the analytical power, and sharp critique, this work should be compulsory reading for anyone interested in rethinking the question of pluralism and political ontology. In his pars destruens, Paipas' book is, in fact, a small masterpiece of deconstruction of the latent presuppositions, hidden perils, and 'repressed memories' that characterise theoretical approaches to pluralism. And yet, the search for a new ethical and political subjectivity, alternative to that forged by the Western liberal tradition, remains open. Today, we are still in the same situation as the watchman of Edom - recalled by Max Weber in one of his vocational conferences who was asked, 'how long will the night still last?' He famously replied, 'morning comes, but it is still night. If you will inquire, come back another time'.

\section{References}

Kantorowicz, E.H. (1997). The King's Two Bodies: A Study in Medieval Political Theology. Princeton, NJ: Princeton University Press.

Nietzsche, F. (2007). On the Genealogy of Morality. Cambridge: Cambridge University Press.

Antonio Cerella

Kingston University, Kingston-upon-Thames KT1 2EE, UK a.cerella@kingston.ac.uk

(C) 2018 Macmillan Publishers Ltd., part of Springer Nature. 1470-8914 Contemporary Political Theory Vol. 18, S4, S232-S235 S235 